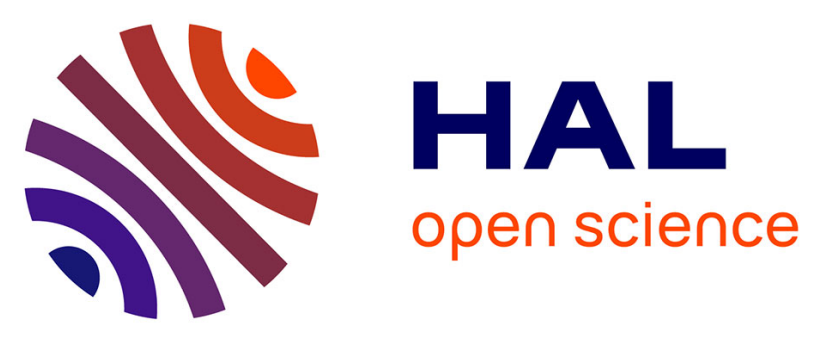

\title{
PD-0042: Development of a new virtual source model for portal image prediction
}

Isabelle Chabert, Delphine Lazaro, Eric Barat, Thomas Dautremer, Thierry Montagu, Mathieu Agelou, Pascal Dupuis, F. Gassa, Loïc de Carlan

\section{- To cite this version:}

Isabelle Chabert, Delphine Lazaro, Eric Barat, Thomas Dautremer, Thierry Montagu, et al.. PD0042: Development of a new virtual source model for portal image prediction. ESTRO 33, Apr 2014, Vienna, Austria. , Radiotherapy and Oncology, 111 (Supplement 1), pp.S14-S15, 2014, ESTRO 33, 4-8 April 2014, Vienna, Austria. 10.1016/S0167-8140(15)30147-X . hal-02268513

\section{HAL Id: hal-02268513 https://hal.science/hal-02268513}

Submitted on 21 Aug 2019

HAL is a multi-disciplinary open access archive for the deposit and dissemination of scientific research documents, whether they are published or not. The documents may come from teaching and research institutions in France or abroad, or from public or private research centers.
L'archive ouverte pluridisciplinaire HAL, est destinée au dépôt et à la diffusion de documents scientifiques de niveau recherche, publiés ou non, émanant des établissements d'enseignement et de recherche français ou étrangers, des laboratoires publics ou privés. 


\title{
Development of a new virtual source model for portal image prediction
}

\author{
Chabert $^{1}$, D. Lazaro ${ }^{1}$, E. Barat ${ }^{1}$, T. Dautremer ${ }^{1}$, T. Montagu ${ }^{1}$, M. Agelou ${ }^{1}$, P. Dupuis² , F. Gassa² , \\ L. De Carlan ${ }^{1}$ \\ 1 CEA LIST, DM2I, Gif sur Yvette, France \\ 2 Leon Berard Center, Medical Physics Unit, Lyon, France
}

Purpose/Objective: Electronic Portal Imaging Devices (EPIDs) are widely used for quality assurance in radiotherapy, and also for dosimetric verifications. For this latter application, the image obtained during the treatment session can be compared to a pre-calculated reference image in order to highlight dose delivery errors. A Monte Carlo(MC)-based method to predict highresolution reference images was recently developed. However, the use of this method in clinical routine is still hampered by the need to store huge phase space (PS) files. This study aims at developing a new virtual source model (VSM) which retains all the existing correlations between particle characteristics stored in the PS file, and hence to provide a more compact way to model the irradiation beam, while keeping the accuracy of using a PS file.

Materials and Methods: A model ofthe studied linac (Elekta Synergy) was first developed using both the MC codes EGSnrc and PENELOPE, and commissioned. Using this model, a reference PSF (PSFr) was calculated after the flattening filter using EGSnrc, where the axial symmetries assumed, and particles were sorted out in three sub-sources according to the position of their last interaction (target, primary collimator or flattening filter). Each particle is described by its radial position ( $r$ ) in the PS plane, its energy $(E)$, and its polar and azimuthal angles (phi, theta), representing the particle deviation compared to its direction after bremsstrahlung, and the orientation of this deviation. For each subsource, a 4D histogram was built by storing the particle distributions according to their $r$, $\mathrm{E}$, phi, theta values. Our VSM hence contains all correlations existing between these four variables contrary to other existing VSMs. This new VSM is now being implemented in the PENELOPE code, and its accuracy is being tested by comparing first the PSF build using our VSM with the PSFr, and then dose distributions in water and portal images calculated with the MSV and PSFr.

Results: Figure 1 shows for each sub-source the correlated 2D histogram depicting particle energy against their radial position. Some characteristics are shared by all sources. Few particles are beyond the collimator aperture $(4.5 \mathrm{~cm}$ from the linac axis). The annihilation photons at $511 \mathrm{keV}$ are always visible. However, the content of a histogram depends widely of the sub-source it represents: the target produces the most energetic particles. The flattening filter and the primary collimator sub-sources generate particles beyond $4.5 \mathrm{~cm}$ of lower energy, because of their large deflection angle. 
Fipre 1. For each sub-sorce, 20 hlstograns deplctine 20 distrlbutions

of particle energy agairst their radial position in the PS plane
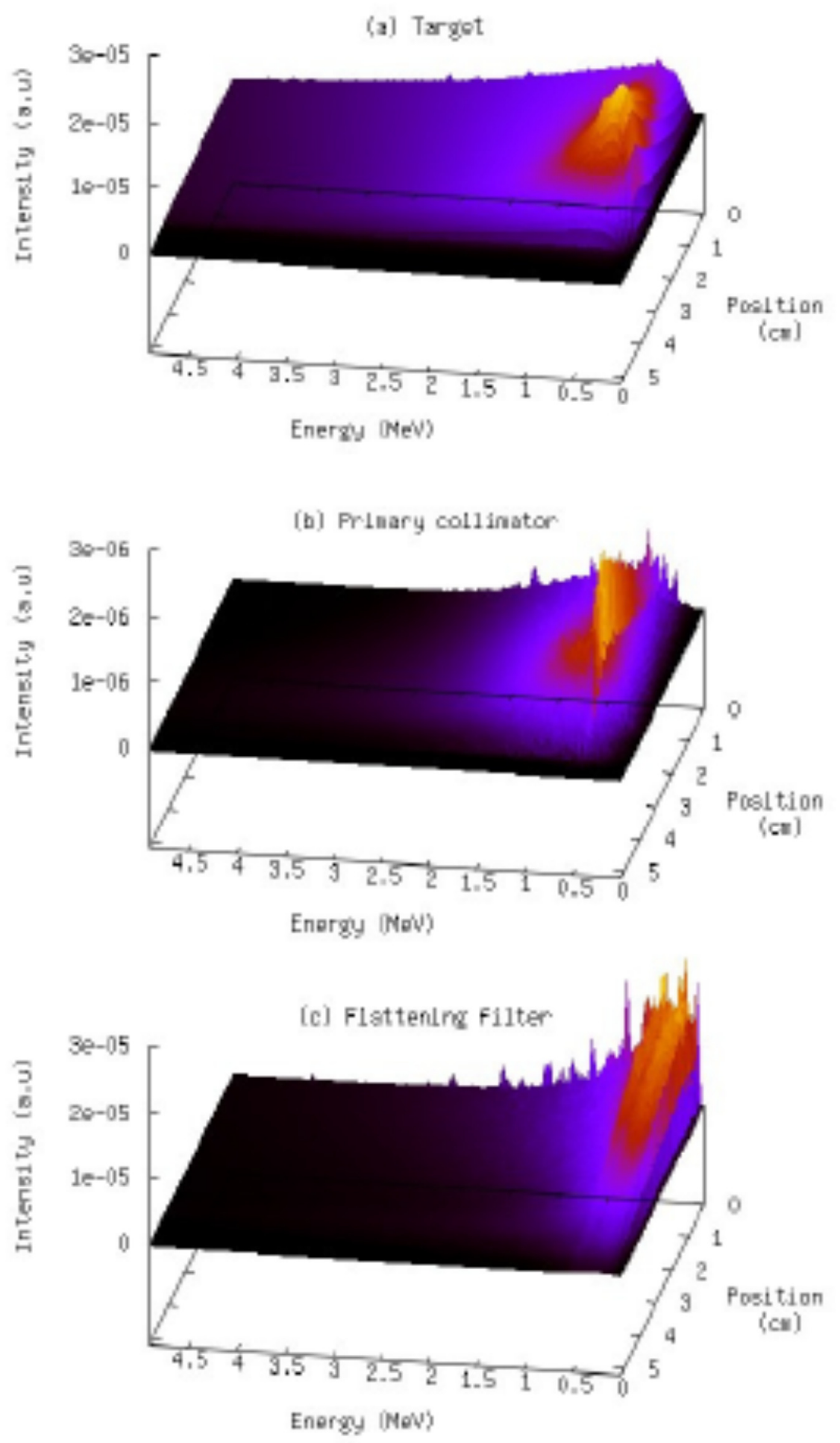

Conclusions: A new VSM taking into account for all correlations between particle characteristics was developed and implemented in the PENELOPE code. It will be used to calculate accurate reference portal images for quality assurance in radiotherapy. 